\title{
PHILOSOPHY OF MATERIAL LOGICS LEARNING TAUHID THE NATURE OF TWO-TWENTY WORK HABIB USMAN BIN YAHYA IN ISLAMIC RELIGION EDUCATION
}

\author{
Nurhadi \\ Islamic College (STAI) Al-Azhar Pekanbaru Riau \\ alhadijurnal@gmail.com ; alhadicentre@yahoo.co.id
}

\begin{abstract}
Aqidah Taubid is belief and knowledge which addresses the form of God, the obligatory nature, the nature of jaiz and the impossible nature. Islam among complete religions teaches Tawheed ablisunnah waljama'ah, in the frame of 'Asy'ariyah Maturidiyah, which contains the characteristics of twenty charities ma'rifah, because awaluddin ma'rifatullah" started the religion of knowing God ". Knowing God means having a religion, not knowing Allah means having no religion (infidel). Five Pillars of Islam, the first pillar of the science of monotheism or aqeedah. Learning taubid must understand the three laws, namely law 'Aqal, adat and syariat. These three laws are called theories of philosophical aqeedah, the easiest theory to know God with the twofold concept. It consists of four parts, namely the nature of nafsiyah (wrijud), salbiyah (qidam, baqa, mukhalafatu lil hawadist, qiyamu bi nafsibi and wabdaniyat), maknawi (qudrat, iradat, knowledge, hayat, sama', basar and qalam) and maknawiyah (presence, student, aliman, bayyan, sami'an, basiran and mutakalliman). These twenty traits have ta'aluq, namely the nature of qudrat and iradat ta'aluq ta'sir, the same nature', basar and the knowledge of ta'aluq incisive, the nature of kalam ta'aluq is done. The twenty characteristics are grouped into two properties, namely istighna 'and iftiqar. This is the core content of the content "laa ilaaha illa allah". The second monotheism is the monotheism of the Prophet Mubammad who has the mandatory four characteristics, namely: siddiq, trust, tabigh and fatanah..
\end{abstract}

Keywords: Philosophy of Logic, Material, Learning, Tawheed, the Nature of Twenty

\section{INTRODUCTION}

All teachings of divine religion teach monotheism "laa ilaha illa Allah" there is no god but Allah. The most famous prophets and apostles inspired humans to believe in Allah is Prophet Ibrahim, in the qisatu al-azbiya al-Qur'an about Abraham seeking God (Allah). this is stated in the Qur'an sura al-An'am verses 75-79. The verse is as follows:

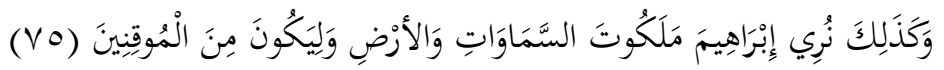

Islamika : Jurnal Keislaman dan Ilmu Pendidikan

Volume 1, Nomor 2, Juli 2019; 49-78

https:// ejournal.stitpn.ac.id/index.php/islamika 
75). And thus We show Abraham the signs of majesty (we are there) in the heavens and the earth and (we show them) so that He is included in the belief. ${ }^{1}$

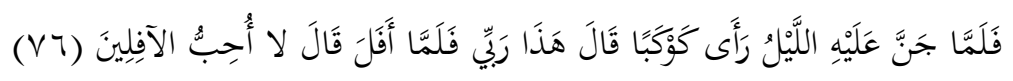

76). When the night was dark, He saw a star (then) He said: "This is my Lord", but when the star sank He said: "I do not like those who drown. ${ }^{2}$

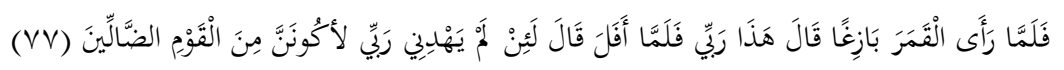

77). Then when He saw the rising moon He said: "This is my Lord". but after the moon went down, He said: "Surely if my Lord does not guide me, surely I am including a perverse person. ${ }^{3}$

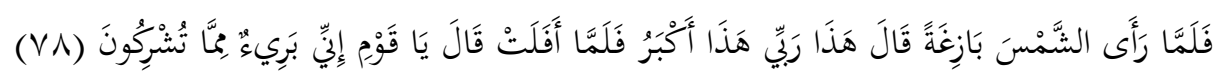

78). Then when he saw the sunrise, he said: "This is my Lord, this is greater." So when the sun set, He said: "O my people, Surely I am free from what you associate. ${ }^{4}$

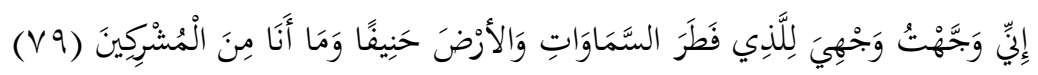

79). Indeed, I confront myself with the Rabb who created the heavens and the earth, by tending to the true religion, and I am not including those who associate partners with God. ${ }^{5}$

From the five verses, Prophet Ibrahim realized, with his logic logic reasoning that all of them are not gods, there must be someone who is stronger and regulates and makes it all, who is it, then continued with verse 162 surah al-'An'am as follows:

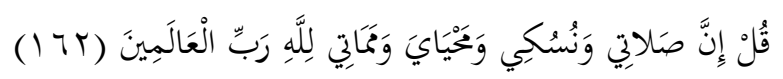

162). Say: Verily my worship, my worship, my life and my death are only for Allah, the Lord of the Worlds. ${ }^{6}$

${ }^{1}$ RI Ministry of Religion. (2015), Al-Qur'an and Translation. Semarang: Toha Putra, p. 199

${ }^{2}$ RI Ministry of Religion. (2015), Al-Qur'an and Translation, p. 199

${ }^{3}$ RI Ministry of Religion. (2015), Al-Qur'an and Translation, p. 199

${ }^{4}$ RI Ministry of Religion. (2015), Al-Qur'an and Translation, p. 199

5RI Ministry of Religion. (2015), Al-Qur'an and Translation, p. 199

${ }^{6}$ RI Ministry of Religion. (2015), Al-Qur'an and Translation, p. 216 
From this last verse, it gives a signal that Prophet Ibrahim already knew Allah, so that everything was only for Allah, so that people and Muslims should, should know Allah. One way to know God is by learning monotheism or aqeedah. The easiest theory is the theory of Prophet Ibrahim above, namely aqidah philosophy philosophy. This has been facilitated by the scholars, so that they have written a lot of the book of monotheism, dianatara small book and very easy to understand and speak Arabic or Arabic Malay is a book written by Habib Usman bin Yahya, known by the nature of twenty, see the content between contents the book below:
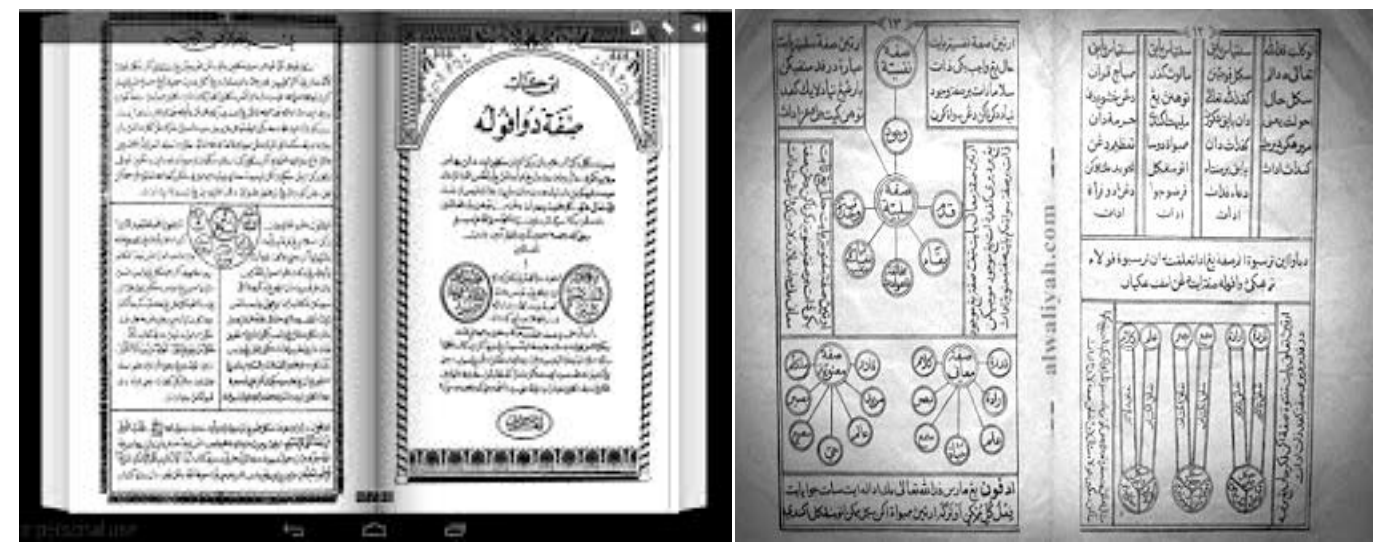

Through this twenty-book, the writer wants to explain the learning theory of tauhid aqeedah of Islamic religious education (PAI) based on philosophy of logic. This theory is caused by the writer because Muslims have been in contact with nonMuslim human beings who tend to negate logical reasoning, such as Atheists and others.

Through this background, the authors want to explain in this paper what is called aqeedah tauhid and how its application in the theory of philosophical logic the nature of twenty books written by habib Usman bin Yahya?

\section{DISCUSSION}

\section{The essence of Aqidah and Tauhid}

The word "Aqidah" is taken from the basic word "al-'aqdu" which is ar-rabth (bond), al-Ibraamal-ihkam (endorsement), (strengthening), at-tawatstsuq (being sturdy, strong), ash-syaddu biquwwah (binding strongly), at-tamaasuk (pengokohan) 
and al-itsbaatu (determination). Among them also mean al-yaqiin (belief) ${ }^{7}$ and aljazmu (determination). "Al-'Aqdu" (bond) opposite the word from al-hallu (decomposition, release). And the word is taken from the verb: "'Aqadahu" "Ya'qiduhu" (binding), "' Aqdan" (oath bond), and "'Uqdatun Nikah" (marriage bond). Allah says, "Allah does not punish you because of your oaths it is not intended (to swear), but he punishes you because of the oaths you deliberately ... "(Al-Maa-idah: 89). ${ }^{8}$

Aqidah means provisions which have no doubt on the person who makes the decision. ${ }^{9}$ While the meaning of aqeedah in religion means that it is related to beliefs not actions. Like aqeedah with Allah and sent to the Apostle. The plural form of aqeedah is aqa-id. (See language dictionary: Lisaanul 'Arabic, ${ }^{10}$ al-Qaamuusul Muhith ${ }^{11}$ and al-Mu'jamul Wasith ${ }^{12}$ : (chapter:' Aqada) So the conclusion, what has become a determination of a person is definitely aqeedah, whether true or false. ${ }^{13}$

In terminology, the case that must be justified by the heart and soul becomes peaceful because of it, so that it becomes a firm and firm reality, which is not interfered with by doubts and doubts. ${ }^{14}$

According to Hasan al-Banna, aqeedah is something that requires your heart to justify it, which makes your soul calm, calm to him and which makes you clean from doubt. ${ }^{15}$ In other words, the faith that certainly does not contain any doubt in the people who believe. ${ }^{16}$ And must be in accordance with reality; who do not accept

\footnotetext{
${ }^{7}$ Munawwir. Ahmad Warson. (1997). Dictionary of Al-Munawwir. Surabaya: Progressive literature. p. 953

${ }^{8}$ RI Ministry of Religion. (2015), Al-Qur'an and Translation, p. 176; Al-Atsari, Abdullah bin Abdul Hamid. (2010). Al-Wajiiz fii Aqiidatis Salafis Shaalib (Sunnah wal Jama'ah Ablis), or Essence of Aqidah Ablus Sunah wal Jama'ab), happened. Farid bin Mubammad Bathathy. Library of Imam Shafi'I, p. 33

${ }^{9}$ Ahmad, Muhammad Abdul Qadir. (2012). Islamic Teaching Methodology, happened. HA. Mostopha. Jakarta: Rineka Cipta, p. 116

${ }^{10}$ Mandzur, Ibnu. (2002). Oral al-Arab. Cairo: Darul hadith, p. 231

${ }^{11}$ Abadi. F. (1996). Qomus Al-Mubith. Ath Thaba'ah Al Khamisah. Bairut: Mu'assah Al-Risalah, p. 373 357

${ }^{12}$ Anis, Ibrahim et al. (1972). Al-Mu'jam Al-Wasit. Egypt: Majma 'Al-Lughah Al-Arabiyah, p.

${ }^{13}$ Al-Atsari, Abdullah bin Abdul Hamid. (2010). Al-Wajiir fii Aqiidatis Salafis Shaalih (Sunnah wal Jama'ah Ablis), p. 34

${ }^{14}$ Jawas, Yazid bin Abdul Qadir. (2006). Syah Aqeedah Ablus Sunnab wal Jama'ah. Library of Imam Ash-Shafi'I, p. 27

${ }^{15}$ Al-Banna, Hasan. (2003). Islamic Aqeedah, happened. H. Hassan Baidlowi. Bandung: al-Ma'arif, p. $1-2$

${ }^{16}$ Husein, Machnun. (2011). Get to know Islam at a glance. Jakarta: Bumi Aksara, p. 17
} 
doubts or prejudices. ${ }^{17}$ If this does not arrive at a brief solid conviction, then it is not called aqeedah. ${ }^{18}$ Named aqeedah, because that person binds his heart on that matter. Its meaning is the faith that must be firm with the Rububiyyah of Allah, His Uluhiyyah, His Apostles, Doomsday, good and bad destiny, all that is contained in the unseen problem, the points of religion and what has been agreed upon by Salafush Salih with submission round to God both in his commands, his law and obedience to him and imitate the Prophet. ${ }^{19}$ If absolutely mentioned, then what is meant is the Ahlus Sunnah wal Jama'ah aqeedah, because that is the understanding of Islam that has been cherished by Allah as a religion for His servants. Islamic Aqeedah is the glorified first three faiths of the generation of friends, Tabi'in and those who follow them well. ${ }^{20}$

According to Ahlus Sunnah wal Jama'ah, the synonym of Islamic aqeedah has other names, including, at-Tauhid, as-Sunnah, Ushuluddiin, al-Fiqbul Akbar, AshShari'iah and al-Iman. Those names are well-known according to the Sunnah in science 'aqeedah. ${ }^{21}$

The second word is tauhid, the word tauhid comes from the words wahhada, yuwahhidu, tauhidan, which means to rule, ${ }^{22}$ to unite. ${ }^{23}$ So, monotheism is a religion that upsets Allah. ${ }^{24}$ The meaning of the word tauhid is to disperse Allah, ${ }^{25}$ what is meant by ruling out Allah is His essence, His character, His asthma and His affinity. ${ }^{26}$ Jubaran Masud writes that Tawheed means "to believe in Allah, the One God", also often equated with "Laa Ilaaha Illa Allah" "there is no God but Allah". ${ }^{27}$

Tawhid is the belief about one or the Essence of God and all thoughts and theories following the arguments that lead to the conclusion that God is one, called

\footnotetext{
17Prodjodikoro, Suyatno. (2011). Aqidab Islamiyyah and its Development. Yogyakarta: Contributions Offset, p. 29

18Al-Banna, Hasan. (2003). Islamic Aqeedah, happened, p. 4

${ }^{19} \mathrm{Al}$-Burnikan, Ibrahim Muhammad bin Abdullah. (2010). Introduction to the Study of Islamic Aqeedah. Mubammad Anis Matta. Jakarta: Robbani Press, p. 141-147

${ }^{20} \mathrm{Al}$-Atsari, Abdullah bin Abdul Hamid. (2010). Al-Wajiiz fii Aqïdatis Salafis Shaalih (Sunnah wal Jama'ah Ablis), p. 34-35

${ }^{21}$ Al-Atsari, Abdullah bin Abdul Hamid. (2010). Al-Wajiiz fii Aqiidatis Salafis Shaalih (Sunnah wal Jama'ah Ablis), p. 35

22Al-bustani, Fuad Iqrami. (2000). Munjid Ath-Thullab. Beirut: Dar Al-Masyriqi, p. 905

${ }^{23}$ Zaini, Shahminan. (2010). Lecture on the Creed of Islam. Surabaya: Al Ikhlas, p. 54

${ }^{24}$ Rais, Amin. (2010). Taubid of Social Formula Combat Gaps. Mizan Bandung, p. 36

${ }^{25}$ Asmuni, M. Yusran. (2003). Science of Tawheed. Jakarta: PT. Raja Grafindo Persada, p. 1

${ }^{26}$ Sabran, Dja'far. (2016). Minutes of Tawheed. Cipitat: Mitra Fajar Indonesia, p. 1

${ }^{27}$ Mas'ud, Jubaran. (1976). Raid Ath-Thullab. Beirut: Dar Al'ilmi Lilmalayyini, p. 972
} 
the Science of Tawheed. It includes questions of trust in Islam. ${ }^{28}$ That belief is called the pillars of faith, whose numbers are six kinds. ${ }^{29}$

Sheikh Muhammad Abduh defines the Science of Tawheed is the Knowledge which deals with the form of Allah, the attributes which are obligatory for Him, the attributes which are attributed to Him, and the characteristics which must be completely abolished from Him (impossible). Also discusses the Apostles of God to determine the truth of the treatise, what is obligatory to him, things that are connected (attributed) to themselves and things that are forbidden to connect to themselves. ${ }^{30}$

The Science of Tawheed is the knowledge that provides provisions for understanding the guiding principles of human life, in navigating the oceans and waves of life. God naturally created God in this world, having different powers between one human being and another. Not a few people in navigating the vast ocean of life, lost direction and guidance, so that he became misguided. That's where the Tawheed science plays a role in giving guidance and direction, so that people always remain aware of their obligations as creatures towards their reversals. ${ }^{31}$

Studying the Science of Tawheed as a study of the very important points of religion is obligatory. Because by studying the Science of Tawheed we will know the good and the bad, then the good must be used as a guideline in faith and giving 'bad 'and that which is badly abandoned. After humanity embraces various basic beliefs and adheres to various ideologies (ism), then they are fragmented and hostile to each other, then Allah knows of the benefit of His servants, decreases His commands to His messengers namely Prophet Muhammad saw. The holy commandment has been conveyed to all humanity on this earth, both to the Arabs or other nations with all wisdom. Allah commands that His servants embrace Islam and believe in Allah.

${ }^{28}$ Rashid, David. (2010). Islam in various dimensions. Jakarta: GIP, p. 1-23

${ }^{29}$ Syafi'i. (2012). "From the Science of Tawhid / Kalam Science to Theology: Epistemological Analysis". Theology, Volume 23, Number 1, 1-15, p. 3

${ }^{30}$ Rashid, David. (2010). Islam in various dimensions, p. 1-23 Analysis", p. 3

${ }^{31}$ Syafi'i. (2012). "From the Science of Tawhid/Kalam Science to Theology: Epistemological 
Spending his whole life to believe and obey the teachings of the perfect Islamic religion. $^{32}$

Studying the science of monotheism is usually driven by the desire to know more and more deeply the understanding of God. Before that, people had faith in God, but still only vaguely. That is because every human being is born by carrying the seeds of faith in his soul. ${ }^{33}$

If Tawheed has entered and permeated the soul of a person, it will grow in the soul of a feeling of willingness for the giving of Allah to himself regarding sustenance and others, a sense of self-respect and respect for others, because monotheistic people view all human beings as equal, originating from one offspring and no one has the right at the meeting or at the slave, the love of one another for fellow human beings. Tawheed people see all human beings as brothers, the monotheistic people live on the basis of humanity and brotherhood, always open, cooperation and mutual cooperation. ${ }^{34}$

\section{The Concept of Philosophy of the Logic of the Twenty Habib Umar bin Yahya}

The first introduction or opening in the book begins with muqadimah, i.e.:

\section{Muqadimah}

All praise be to Allah, the Lord of all the worlds. Perfect prayer and perfect greetings for our lord of the Prophet Muhammad and his family and friends. The enjoyment of Islam and the blessing of faith are the very blessings that Allah has given to the ummah of Islam. Both are conditions to be able to enter heaven eternally in it and survive the torment of hell fire by doing tha'at to Allah. Then it is obligatory for each mukallaf (aqil baligh) that he knows all the pillars of Islam and the pillars of faith so that he is grateful to Allah by practicing both practices which can only be accepted by Allah if we have knowledge. ${ }^{35}$

\footnotetext{
${ }^{32}$ Syafi'i. (2012). "From the Science of Tawhid/Kalam Science to Theology: Epistemological Analysis", p. 3

${ }^{33}$ Rashid, David. (2010). Islam in various dimensions, p. 1-23

34 Syafi'i. (2012). "From the Science of Tawhid / Kalam Science to Theology: Epistemological Analysis", p. 3-4

${ }^{35}$ Yahya, Habib Usman bin. (t.th). The nature of twenty. Jeddah: Singgapore, p. 1
} 
The first pillar of Islam is to say two sentences. The knowledge of the meaning of the two sentences is called ushuluddin or the science of monotheism. It is obligatory for every mukallaf to know God with all His attributes which are obligatory for Him and which are impossible for Him, and which must be for Him. Likewise that which is obligatory for the Apostle and which is impossible, and which must. The knowledge of other pillars of Islam includes the science of jurisprudence, which is obligatory for every believer to know it for the perfection of worship. The Prophet said (which means), "Every person acts charity without knowledge, so his deeds are rejected, not accepted." He also said, "Demanding that knowledge is obligatory on every Muslim. ${ }^{36}$

In the book of Zubad it is said, "The first compulsory for man is to know God with yaqin. "In the Khuthbatul Habib Thahir bin Husayn it is said," Know, O my brother, that Ushuluddin is familiar with those who are worshiped before worship, and that is the essence of the meaning of Kalima". f you have known the obligation of ma'rifatullah for each mukallaf, then it is known to you that ma'rifatullah is jazim (who broke up, who has no doubt) and mufaqah (accordingly) in the matter with theorem. Jazim has four, namely: 1). Jazim praised the matter with the argument, this is ma'rifah. 2). Jazim mufaqah on haq without arguments, this is taqlid saheeh (following the right without theorem). 3). Jazim there is no mufaqah on haq with theorem, this is the ignorant markab (foolish ignorance). 4). Jazim there is no mufaqah on haq without theorem, this is false taqlid (following the wrong without knowledge). ${ }^{37}$

The arguments are things that show the truth of a matter. While the postulate of Allah's form with all His Attributes is sufficient with the ailments of the Ajmaly (the state of the heavens, the earth, and among them). The Word of God:

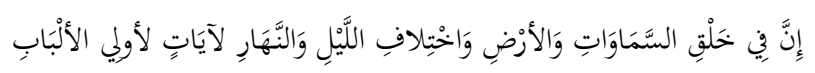

Meaning: Indeed, in the creation of heaven and earth and the alternation of night and day there really are signs for people who have 'aqal. (Ali Imran: 190)

${ }^{36}$ Yahya, Habib Usman bin. (t.th). The nature of twenty, p. 1

${ }^{37}$ Yahya, Habib Usman bin. (t.th). The nature of twenty, p. 1 


\section{Types of Law}

\section{Law 'Aqly}

Law 'Aqly there are three, namely: 1). Mandatory, meaning a case that cannot be absent for q aqal mind. 2). Impossible, meaning a case that cannot not be missed by $q$ aqal. 3). Jaiz, means that the case is present and the absence is acceptable diterima aqal. ${ }^{38}$

\section{Syar'i Law}

Syar'i law is the command of Allah for the act of mukallaf (which is weighted / given responsibility), so-called commands that are burdensome (taklif) are also referred to as clear orders, because the conditions or reasons are determined. There are seven syar'i laws, namely: 1). Mandatory, meaning the case that if done gets a reward and if left gets sin. 2). Sunnah, meaning the case that if done gets a reward. 3). Haram, meaning the case that if done gets a sin and if it is left gets a reward. 4). Makruh, meaning the case that if done does not get a sin, but the action is disliked by Allah and if it is left gets a reward. 5). Mubah, meaning "must be syar'i", which is a case which if done or abandoned does not get sin or reward. 6). Shahih (legitimate), meaning a case that is complete with all the terms and conditions. 7). Bathal, meaning things that lack the terms or pillars. ${ }^{39}$

\section{Law y Ady (Customs / Habits)}

Law y ady means setting a case for a matter, or setting a case for something on the case grounds over and over again. Namely: 1). Inhibition / determination of the situation of a case with other case conditions. For example, a state of fullness with eating conditions. 2). Determination of the absence of a case in the absence of other cases. For example, the absence of satiety in the absence of food. 3). Determining the situation of a case in the absence of another case. For example, cold conditions in the absence of blankets. 4). Determination of the absence of a case with the circumstances of another matter. For example, the absence is charred by the presence of water. ${ }^{40}$

\footnotetext{
${ }^{38}$ Yahya, Habib Usman bin. (t.th). The nature of twenty, p. 2

${ }^{39}$ Yahya, Habib Usman bin. (t.th). The nature of twenty, p. 2

${ }^{40}$ Yahya, Habib Usman bin. (t.th). The nature of twenty, p. 2
} 
Now you already know the difference between obligatory shari'a and the obligatory 'aqly. If it is stated that it is mandatory for you to avoid reading, the meaning is obligatory syar'i. If it is stated obligatory for Allah or for the Messenger of Allah, then the meaning is obligatory wajib aqly. If it is said jaiz for mukallaf, then it means jaiz syar'i. If it is said jaiz for Allah, then the meaning is jaiz 'aqly. ${ }^{41}$

What is obligatory on Allah with tafshil is called the nature of twenty, which has stood up the argument 'aqly and naqly upon it. It is obligatory for every mukallaf to know ijmaly only in words (in the nature of Allah with every character of perfection. The impossible for Allah with tafshil is 20 cases, namely the opposite of twenty characteristics that are obligatory for Allah. The impossible in Allah with ijmaly is in in the words "Exalted in Allah from all the deficiencies and things that are reflected in the heart."

\section{Nature of Nafsiah}

Existence (exists). Impossible 'adam (no).

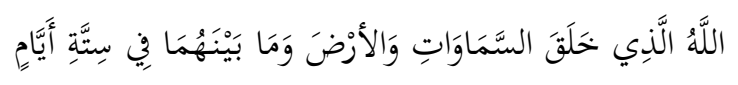

Meaning: Allah Who Created the heavens and the earth and who is between them ... [QS. As Sajdah (32) : 4].

God must be there, it is impossible for God to be non-existent. Something can be called Ada, if it exists by itself. Because 'Ada' is the word active, not passive. So everything that is 'held' is not God, because it is 'held', not 'There'. For example, if a person is paralyzed, he is helped and moved or positioned so that he is in a sitting position. So actually he did not sit but was seated. When he is supported by other people so that he is in a standing position, in fact he does not stand, but is established. God is not held. God is there without being held. ${ }^{42}$

It is inappropriate if we worship something created. It is not appropriate for humans to worship Isa as, Uzair as, statues, Pharaoh, trees, gods, jinn, angels, etc. Because they are all created. Something that is created is not God. Indeed, God is the

${ }^{41}$ Yahya, Habib Usman bin. (t.th). The nature of twenty, p. 2

${ }^{42}$ Yahya, Habib Usman bin. (t.th). The nature of twenty, p. 3 
one who created everything that exists. Allah says in the Qur'an surah Al-Anbiya 'verse 30 which means: And do those who disbelieve do not know that the heavens and the earth are both a united one, then We separate the two. And from water we make everything that lives. So why don't they also believe? [Al-Anbiya: 30]. Then He went to the sky and the sky was still a fog. So He made seven heavens in two times and He revealed to each heaven his affairs. [Shushilat: 11-12] And the heavens We built with (Our) power, and indeed We really expanded them. [Adz-Dzariyat: 47]. That at first God was made of heaven and earth. Then the earth is mixed up, that is, a thing which is covered in dark mist; then the Spirit of God hovers over the waters. [Genesis 1: 1-2 TL]. ${ }^{43}$

In 1929, A.E. Hubble, an American astronomer, presented a great discovery. When he looked at the stars with a giant telescope, he found that the light from the stars changed the tip of the spectrum to red. This means, the star is away from the observation site. This means that stars stay away from the earth permanently. Previously he also found that galaxies and stars moved away from each other. This explains that it turned out that the universe was expanding, "Not static as claimed by atheists. This expanding universe shows that if the universe can move backward in terms of time, then it is found that the universe originates from 'single point'. Calculations show that this single point, containing all the substances or materials in the universe, has 'zero volume' and 'unlimited density'. The universe is created through this explosion of single points with zero volume. This extraordinary explosion called the Big Bang marked the beginning of the universe. The meaning of 'zero volume 'is the absence". ${ }^{44}$

This is proof that Islam is not superstition. Because the belief that the universe was created by God can be explained scientifically. Indeed, the theory which says that the universe is not created is what is an illogical superstitious belief, does not enter aqal, is unscientific, ignorant, misguided. If it is not regulated by God, where might a powerful explosion produce an orderly order as we see it in the universe. As we know, each explosion only produces chaos. It is impossible for a dynamite explosion to produce a magnificent building that is sturdy and beautiful. 
Without the power of God, of course these substances will scatter without control. But in reality, after the Big Bang, the substances moved at a very controlled speed and direction. Of course Allah Yang has kept these substances from being scattered without control. ${ }^{45}$

Allah is not held, but Allah is indeed Existence. God is with Himself. Whereas the adherents of the Law do not exist, but are held. Obviously there is a difference between being held. That is one of the sentences of tauhid (Laa Maujud Illa Allah).

So it is appropriate for the muktaqad believer to dhikr to Allah in every intention. Dhikr can be done in many ways, for example by mentioning Asma Allah or praising Him verbally and also meyaqini with heart; can also remember the ni'mat that God has given; thinking about the beauty and order that is in God's creation including oneself; take lessons from previous figures; take lessons from disaster and

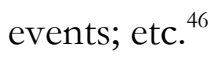

\section{The nature of Salbiyah}

Qidam (Previous). Impossible (new) huduts or preceded by nothingness.

Meaning: He is the First and the Last. [Al Hadid (57) : 3]

God must be the first. God is not preceded by nothingness. Something that begins with nothing means that the original nature is nonexistent. Whereas we have agreed that God is the original nature of 'There'. He Exists because He does exist, if it begins with nothing, then becomes Ada, then who makes him become 'There'? So what makes 'there' is God, and God cannot be held. God must be the first. ${ }^{47}$

So it is not appropriate for us to worship something that is preceded by nothingness. The famous astrophysicist Hugh Ross said, "If the beginning of time coincides with the beginning of the existence of the universe, as explained by space

\footnotetext{
${ }^{45}$ Yahya, Habib Usman bin. (t.th). The nature of twenty, p. 4

${ }^{46}$ Yahya, Habib Usman bin. (t.th). The nature of twenty, p. 4

${ }^{47}$ Yahya, Habib Usman bin. (t.th). The nature of twenty, p. 4
} 
theorems, then the cause of the universe must be a unitary function in a completely separate, and pre-existing time dimension. This conclusion is very important for our understanding of who is God and who / what is not God. Rabb is not the universe (makhluq) itself and is not contained in the universe (both space and time). "He has no child and is not begotten. [QS. Al-Ikhlash (112): 3]. He who is the End and the End. [QS. Al-Hadid (57): 3]. I am the First and I am the End, there is no God but Me. [Isaiah 44: 6]. ${ }^{48}$

Allah is Being (There). That is the nature of God. Whereas 'adam (tiada) is not the nature of God. God is not preceded by nothingness. Nothing is God's creation. What other than Allah does not exist (actually). Allah Is There Even though the Throne has not been held. Allah is Qidam (Previous). Whereas the makhluq is the later one. Humans and jinns don't exist. Then God created both. Some are created by infidels and some are created by mu 'min. Then it is worthy for mukmin muktaqad to give thanks to Allah for making us mu'min and Muslims with His taufiq. ${ }^{49}$

Baqa` (Eternal). Impossible to perish (mortal) or contact / experience nothingness.

$$
\text { وَيَبْقَى وَجْهُ رَبِّكَ ذُو الجَحلالِل وَالإِكْرَام }
$$

Meaning: And the eternal Essence of Allah Who has Greatness and Glory. [The beneficent (55) : 27]

God must be eternal, God cannot be temporary. Allah Is, Allah is the End, when all the creatures have perished, God remains. God does not experience pain, is not sleepy, does not sleep, is not tired, let alone perish. Allah, there is no God (who has the right to be worshiped) but He Who has eternal Life continues to take care (His creatures); not sleepy and don't sleep. What belongs to the heavens and the earth. No one can give intercession by Allah without His permission. God knows what is before them and behind them, and they know nothing of the knowledge of God but what He wants. God's chair covers heaven and earth. And Allah does not feel hard to maintain both, and Allah is High, Great. [QS. Al-Baqarah (2): 255]. Don't 
you know, and don't you hear? The Lord is the eternal God who created the earth from end to end; He did not become tired and did not become lethargic, His understanding was unexpected. [Isaiah 40:28] So it is inappropriate for us to worship something that is experiencing pain, fatigue, let alone perish. In the Bible it says: There is Jacob's well. Jesus was very tired from the journey, so he sat on the edge of the well. [John 4: 6] Suddenly a hurricane raged on the lake, so the boat was swallowed by waves, but Jesus slept. [Matthew 8: 24]..$^{50}$

Because the universe, including us, is impermanent, we should prepare ourselves to face death and generation day. And do not cause damage on the earth, after (Allah) has repaired it and prayed to Him with fear (will not be accepted) and hope (will be granted). Surely the mercy of Allah is very near to those who do good. (Q.S. Al-A'raf: 56). Then when a great disaster (the Day of Judgment) has come. On the day (when) man remembers what he did, and hell is shown clearly to everyone who sees. As for those who transgress the limits, and give priority to the life of the world, then truly is the place of residence. And as for those who fear the greatness of their Lord and refrain from the desires of their lusts, then indeed the heaven is the abode. (Q.S. An-Naazi'aat: 34-41). ${ }^{51}$

To understand about all the universe and the relativity of time, we explain a little here that the universe is like a dream. Material is just imagination. When we dream, we feel that we are walking, moving, touching something, feeling something, hearing something; even though it's just imagination. But the imagination that we feel in the 'real world' is a sign of what we will experience in the next world. Are we going to "wake up from a dream" then feel a beautiful "dream", or we "wake up from a dream" then feel a bad "dream". And the trumpet was blown, so suddenly they came out immediately from their tomb (towards) to their Lord. They said: "Ouch woe to us! Who raised us from our bed (grave)? "This is what was promised (God) the Most Gracious and true the Apostles (Him). It is not the shout except for a single shout, then suddenly they are all gathered to Us. Then on that day no one will be harmed at all and you will not be rewarded except with what you have done. (Q.S. Yaa Siin: 51 54). On the day they saw the day of the resurrection, they felt as if they were not

${ }^{50}$ Yahya, Habib Usman bin. (t.th). The nature of twenty, p. 5

${ }^{51}$ Yahya, Habib Usman bin. (t.th). The nature of twenty, p. 5 
staying (in the world) but (for a while) in the afternoon or morning. (Q.S. AnNaazi'aat: 46). Or do you (those who do not pay attention) through a country that (the wall) has fallen over the roof. He said: "How did God revive this country after it was destroyed?" So God killed the man a hundred years, then brought him back to life. God asked: "How long have you lived here?" He replied: "I have lived here a day or half a day." Allah said: "Actually you have lived here a hundred years; look at your food and drink which has not yet changed; and look at your donkey (who has become a bone); We will make you a sign of our authority for humans; and look at the donkey's bones, then We rearrange it, then We wrap it with meat ". So when it was revealed to him (how God brought to life the dead) he said: "I am sure that Allah is All-Powerful over all things." (Q.S. Al-Baqarah: 259). Allah asks: "How many years have you lived on earth?" They replied: "We live (on earth) a day or half a day, then ask those who count." Allah says: "You do not live (on earth) but just a minute, if you really know. "(QS Al-mu'minun: 112-114). And they ask you that the punishment be hastened, even though Allah will not violate His promise. Surely a day by your Lord is like a thousand years according to your calculations. (Q.S. Al-Hajj: 47). ${ }^{52}$

Maybe you have seen flora films about the growth of a seed. You see the seed grows in just a few seconds until it becomes an adult plant. In fact, it takes weeks to grow into an adult plant. Know that what you see in the film is an accelerated event. But the film - if he can feel like a human - does not feel that he is undergoing acceleration. He feels normal. He feels each frame normally. He felt that day and night changed normally. But that is the film's calculation. Whereas for us day and night - from seeds to mature plants, the film takes place in just a few seconds. It turns out that the film's calculation of him is different from our calculation of the film. ${ }^{53}$

God is there. It is impossible not to exist or to experience nothingness. Allah Is There Even though the Existence does not exist. God is the End. God does not experience pain, sleepiness, sleep, fatigue, let alone perish. Whereas there is no makhluq. Then it was held. 
So it is fitting for the muktaqad believer to remember that he will die so that he will rest and repent to Allah. ${ }^{54}$

مُخَالَفَةُ لِلْحَوَادِثِ

Mukhalafatu lil hawadits (Unlike the new one). God is impossible with the new one.

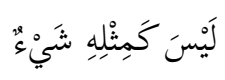

Meaning: Nothing is like Him anything. [Ash Shura (42) : 11]

God must be different from the universe. There is no way God is the same as His creation. Allah is omnipotent, while beings are weak, but Allah gives them power. There is no one who is equal to Him. [QS. Al-Ikhlash (112): 4]. Nothing like Him anything. [QS. Ash-Shura (42): 11]. He gives strength to those who are tired and increase their enthusiasm to those who are powerless. [Isaiah 40-29] Who is like me? [Isaiah 44: 7]..$^{55}$

By studying the nature of God, we will see how powerful God is and how weak people are. We will see that God is indeed different from his people. ${ }^{56}$

So it is appropriate for the muktaqad believers to worship Allah.

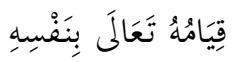

Qiyamuhu Ta'ala bi Nafsihi (Standing Allah with Himself). It is impossible for God not to stand with Himself.

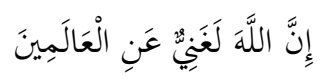

Meaning: Surely Allah Ta'ala is rich than the universe. [Al-Ankabut (29) : 6]

God does not need anything else. God does not need to eat, not hungry, not thirsty, does not need water, does not need air, does not need the universe. Our devotion and evil do not affect the power and kingdom of God. Surely the Rich God does not need the universe. [QS. Al-Ankabut (29): 6]. God is God who depends on everything. [QS. Al-Ikhlash (112): 2]. ${ }^{57}$

So it is inappropriate if we worship something that is faqir. It is inappropriate for us to worship something that requires food from God. On the morning of his

${ }^{54}$ Yahya, Habib Usman bin. (t.th). The nature of twenty, p. 6

${ }^{55}$ Yahya, Habib Usman bin. (t.th). The nature of twenty, p. 7

${ }^{56}$ Yahya, Habib Usman bin. (t.th). The nature of twenty, p. 7

${ }^{57}$ Yahya, Habib Usman bin. (t.th). The nature of twenty, p. 7 
journey to the city, Jesus felt hungry. Near the road he saw a fig tree and went to it, but he found nothing on the tree except leaves. [Matthew 21:18-19].

The Bible verse above shows that Jesus was only an ordinary human who felt hungry, and he did not know, when was the season for figs. Faqir (needs something other than himself) and does not know is not the nature of God. ${ }^{58}$

God exists without being created. There is no God but Allah. God Who Created the Universe. God does not need adoration. But the adversary needs God. God is the Rich, while we are faqir. Our devotion and evil do not affect the power of Allah. Whereas there is a consensus by being held..$^{59}$

So it is proper for mu 'min muktaqad to express his need only to Allah.

Wahdaniyah (Esa His Essence and One His Nature and One of His Actions). It is impossible to say His Essence or His Nature or His Actions.

Meaning: (Say O Muhammad): Allah Is One. [Al-Ikhlas (112) : 1].

God is one, single. It is impossible for God to be split or separated. There is no way that some of God is in heaven and some are on earth. Jesus answered, "The main law is lah Listen to the people of Israel, Lord our God, God is One. "' [Mark 12: 29]. ${ }^{60}$

Throughout the New Testament, Jesus always said that God is Single, never Jesus said that God is Trinity. Even in the Old Testament, the Jews believed that God was Single, not Trinity. ${ }^{61}$

The essence, nature and deeds of God are One. Not separated. The Qur'an is Allah. The Qur'an is Kalamullah. Kalamullah is Qidam. Qidam is Allah. Allah is Qidam. What besides Allah is the huduts (later). Alim (Knowing) is God. Bashir (Seeing) is God. All Attributes and Acts, and the Essence of God are Single. It's different from makhluq. The human body is created. Human hearing is created. Human vision was created. Humans hear by conveying the voice to humans by God.

${ }^{58}$ Yahya, Habib Usman bin. (t.th). The nature of twenty, p. 8

${ }^{59}$ Yahya, Habib Usman bin. (t.th). The nature of twenty, p. 8

${ }^{60}$ Yahya, Habib Usman bin. (t.th). The nature of twenty, p. 8

${ }^{61}$ Yahya, Habib Usman bin. (t.th). The nature of twenty, p. 8 
The seeing act that belongs to man is created by God. All human characteristics such as being able to hear, be able to see, can speak, are all Allah's creations (makhluq). All human actions such as hearing, seeing speaking, walking, standing, worshiping, all of that was created by Allah. All the scratches of the human heart, his will, the plan is makhluq (created by God). Earth was created by God. Played by God. Folded by God. Home created by God. Detained and torn down by God. All creation (makhluq) is certainly created, and the Creator (Al-Khaliq) is only Allah. There is no god but Allah Who created the universe.

So it is appropriate for the mukmin muktaqad to remember the acts of God for each incident. ${ }^{62}$

\section{The nature of Ma'ani}

Qudrah (Almighty) It is impossible for God to be weak.

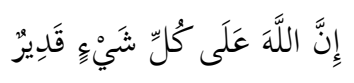

Meaning: Surely Allah has power over everything. [QS. Al-Baqarah (2): 20]

Then the Holy One (Allah) in His hand has authority over everything and to Him you are returned. [QS. Ya Sin (36): 83]. And (as) an Apostle to the Children of Israel (who said to them): "Verily I have come to you with a sign (miracle) from your Lord, that is, I made for you from a bird-shaped land; then I blew it, then he became a bird with the permission of Allah; and I healed people who were blind from birth and people with diseased hair; and I revive the dead by the permission of Allah; and I tell you what you eat and what you keep in your house. Indeed, in that is a sign (my righteousness) for you, if you truly believe. "[Q.S. Ali 'Imran: 49]. The works that I did in the name of the Father, that gave testimony of me (that I was an apostle). [John 10:25] And He (Allah) gave him power (to Jesus) [John 5:27]. Jesus said: Children do not do things from themselves. The Son revives whomever the Father wants. [John. 5:19, 21]. Jesus said: I can do nothing from myself. [John. 5:30]. Jesus said: "I have been given all power ..." [Matt. 28:18]. Then Jesus entered the temple,

${ }^{62}$ Yahya, Habib Usman bin. (t.th). The nature of twenty, p. 8 
and when he taught there, the chief priests and elders of the Jewish people came to him, and asked, "By what power have you done these things? And who gave them the power -Your?" Jesus replied to them: "I will also ask you a question, and if you give me an answer, I will tell you what power I am doing. Where is John's baptism? From heaven or from man?" They discussed it among them, and said: "If we say: From heaven, He will say to us: Then, why do you not believe in him? But if we say: From men, we fear the people, because everyone considers John is a prophet. " Then they answered Jesus: "We don't know." And Jesus said to them: "If so, I also do not tell you by which power I do these things." [Matthew 21: 23-27]. ${ }^{63}$

In the Qur'an and the Bible it is explained that Jesus' power is from God, not of himself. As said earlier, that the creature was created by God. The same is true of his actions and nature. Allah has power over the people. The nature and deeds of a creature are adherents. Whereas the admiral is not in power. You cannot move to worship or even avoid repentance. His character is weak, paralyzed, unable to do anything, so the author is unable to do anything. Only God does. God Who Turns Hearts. But remember, Allah is omniscient, most just, most wise and knows wisdom (Al-Hakam). Whereas humans are very stupid and evil. What humans know is very little when compared to what is unknown to humans. So it is inappropriate for humans to brag about being weak. There is no power to avoid evil and there is no power to do good except with love and power of God. ${ }^{64}$

So it is appropriate for the muktaqad believer to tawadhu ', not takabbur, and many fear Allah.

Iradah (Most Willing). It is impossible for God to have no will.

Meaning: God does what He wants. [Al-Buruj (85) : 16]

Jesus said: "I do not obey my own will, but I obey the will of the One who sent me." [John 5:30]. I came not by my own will, but at the will of the One who sent me. [John. 8:42].

${ }^{63}$ Yahya, Habib Usman bin. (t.th). The nature of twenty, p. 9

${ }^{64}$ Yahya, Habib Usman bin. (t.th). The nature of twenty, p. 9 
Then it is clear that Jesus is controlled by the will and power of God. Jesus did not have power over himself. How can God be mastered? So Jesus is not God, he is not God. Jesus is only the messenger of God. ${ }^{65}$

God is omnipotent and wants to do what he wants, not as the other party wants. What God wants will happen. What is not desired by God certainly does not happen (no). If He Wants something, then he simply says, "Kun (So)", then it happens (see Yaa Siin verse 82). And God is the Good. What God wants is kindness. But the stupidity of humans cannot penetrate the Wisdom of Al Hakam. ${ }^{66}$

Each event is related to time. If God experiences, "Kun" at every event and time means that God is caught in time? No, not so. God Is Experienced, "Kun" and all events from beginning to end in the universe are created. But humans feel each frame of life alternately so they feel that time is there. Even though time, like matter, is only imagination. ${ }^{67}$

You may have dreamed which time in the dream you felt you lived very long. But when you wake up, you only fall asleep for several tens of minutes. What you feel as time turns out to be imagination.

In Surat Al-Hajj verse 14, Allah explains that those who enter those who believe and do good deeds are Allah. That's how God does what He wants. Lo! Allah has included those who believe and do righteous deeds into Gardens beneath which rivers flow. Allah does what He wants. [QS. Al-Hajj (22): 14]. ${ }^{68}$ Then it is appropriate for mukmin muktaqad to thank Allah Ta'ala for each ni'mat and bershabar for each mushibah.

'Ilmun (Know) It is impossible for God to be ignorant (stupid).

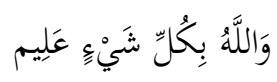

Meaning: And Allah with every thing is Knower. [Al-Hujurat (49) : 16].

See also 2: 29,231,282; 6: 115; 9: 115; 57: 3. (Unbelievers) ask you (Muhammad) about that time (the last day), when will it occur? Who can you (so) say

${ }^{65}$ Yahya, Habib Usman bin. (t.th). The nature of twenty, p. 9

${ }^{6}{ }^{6}$ Yahya, Habib Usman bin. (t.th). The nature of twenty, p. 9

${ }^{67}$ Yahya, Habib Usman bin. (t.th). The nature of twenty, p. 10

${ }^{68}$ Yahya, Habib Usman bin. (t.th). The nature of twenty, p. 10 
(time)? To your God the end is returned (the provisions of time). You are only a reminder for those who are afraid of him (at that time, the day of awakening). On the day they saw the day of the resurrection, they felt as if they were not staying (in the world) but (for a while) in the afternoon or morning. [QS. An-Nazi (79): 42-46]. But about that day and moment no one knows, angels in heaven do not, and children do not, only the Father himself. [Matthew 24:36]. ${ }^{69}$

God knows everything, even though something-according to us-has not happened. Allah knows what is hidden and what is revealed. Then it is appropriate for the mukmin muktaqad to be afraid of acting against Allah, because Allah is Allknowing of each of our actions.

Hayah (Life) It is impossible for God to die.

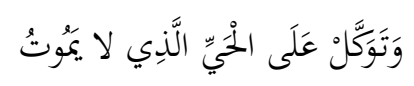

Meaning: And surrender yourself (resignation) to the One Who lives the One who does not die. [Al Furqan (25): 58]

See also 2: 255; 3: 2. God is Life. God's life does not come from anyone, but God lives with Himself. And it is impossible for God to die. Whereas the life of the creature comes from Allah. ${ }^{70}$

For just as the Father has life in Himself, so too does the child have life in him. [John. 5:26]

God cannot die. But we must die. There is no power other than Allah. And actually including a very heavy test is death. We are not there, then are held, then to God our place is back.

Then it is worthy for mukmin muktaqad to put your trust (surrender) to Allah. $^{71}$

Sama '(Hearing). It is impossible for God to be deaf.

\footnotetext{
${ }^{69}$ Yahya, Habib Usman bin. (t.th). The nature of twenty, p. 10

${ }^{70}$ Yahya, Habib Usman bin. (t.th). The nature of twenty, p. 10

${ }^{71}$ Yahya, Habib Usman bin. (t.th). The nature of twenty, p. 11
} 
Meaning: And Allah hears again Understanding. [Al-Baqarah (2) : 256]

Allah knows. He heard and answered the prayer addressed to Him. As for the granting of prayer, sometimes Allah grants what we want, sometimes Allah grants what God wants, and it is good for the prayer, and sometimes God suspends that prayer and is replaced with a better one in the hereafter. So the prayer is not to ask for what we want. But to convey our desires. And God likes His servants who pray to Him. With His liking, God gave the best to the servant. If what is desired by the servant is indeed good, then Allah grant it as desired. If what the servant wants is bad or bad, then God gives a better than what the servant wants. And if it is granted in this world as the servant wants it to be bad, then God suspends it and replaces it with a better one, namely with His forgiveness and love in the hereafter. But there are times when someone is praying, and that can be bad for him, then God grants him so that he is further away from God. So this is istidraj. God let him fall asleep in keni'matan, so that on the Day of Judgment, Allah can torment him with a painful punishment caused by his kufr. And Allah has heard again knowing that [QS. AlBaqarah (2): 256]. Jesus prayed: "My Father, if possible, let this cup come from me, but do not be what I want, but as you will." [Matt. 26:39].

Even Jesus prayed all night with sincerity to be saved from the crucifixion. And he gave to God what was best for him. For Allah knows what is best for His servants whom He loves. From here, would you say that Jesus was willing to be crucified? No, Jesus was not willing to be crucified. There is no such thing as "salvation through the crucifixion of Jesus." Jesus was sent not to be crucified, but to save Israel from destruction by teaching aqeedah and the way of life (shari'a) that God blessed. The crucifixion of Jesus is not God's command. If that is God's command, why is Jesus reluctant to be crucified. Whereas Abraham and his son were willing to carry out God's commands. The crucifixion of Jesus was the fruit of the malice of Jewish priests. In order not to be blamed, they made this strange doctrine through Paul's mouth full of lies. ${ }^{73}$

${ }^{72}$ Yahya, Habib Usman bin. (t.th). The nature of twenty, p. 11

${ }^{73}$ Yahya, Habib Usman bin. (t.th). The nature of twenty, p. 11 
God knows all our words. Even what we say to ourselves. Allah understands all good and bad words.

So it is proper for the muktaqad believers not to say unlawful, for Allah understands all words.

Bashar (Seeing). It is impossible for God to be blind.

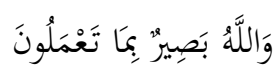

Meaning: And Allah knows what you do. [Al Hujurat (49) : 18]

So it is fitting for the mukmin muktaqad that he does not make immorality, because Allah sees all deeds. ${ }^{74}$

Kalam (Saying / Saying). It is impossible for God to be silent (mute).

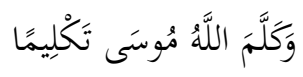

Meaning: And said Allah to Moses perfectly / truly said. [An Nisa` (4): 164]

All things are made by God with His words, "Kun" (be), then be everything. With His Asma everything happens, with His Asma all things begin, and to Him everything returns. He is the one who turns on and off, so when He sets something up, He just says to him: "Be", then be it. [QS. Al Mukmin (40): 68]. Indeed, His command when He wants something is only to say to him: "Be!" Then it happens. [QS. Ya Sin (36): 82]. By the word of the Lord the heavens were made, by the breath of His mouth all His soldiers [Psalm 33: 6] For He said, all things were done, He gave orders, so everything was there. [Psalm 33: 9] God said: "Be ..." [Gen. 1: $3,6,9,11,14,20,24,26]$

So it is appropriate for the mukmin muktaqad to do a lot of dhikr to Allah Ta'ala with the hope of Asma Allah. ${ }^{75}$

${ }^{74}$ Yahya, Habib Usman bin. (t.th). The nature of twenty, p. 11

${ }^{75}$ Yahya, Habib Usman bin. (t.th). The nature of twenty, p. 12 


\section{The nature of Ma'nawiyah}

Qadiran (Who Is Mastering) Impossible God is a weak One.

The argument is the proposition of the nature of Qudrah. The Prophet said, which means, "For the sake of the One Who has no god but Him. Indeed, one of you has done the deeds of the people of heaven. But when his journey was left a cubic more, because of the provisions of taqdir he could turn around doing the deeds of the inhabitants of hell (su 'ul khatimah). On the contrary, one of you has practiced the occupants of hell. But when his journey was left a cubic more, because of the provisions of taqdir he could turn around doing the deeds of the inhabitants of heaven (husnul khatimah), so that he could enter into it.. ${ }^{76}$

The Prophet also said which means, "Every one of you, or every soul that breathes, has been determined by Allah in heaven or hell. Even by Allah it has also been determined whether he is a wretched person or a happy person. "A man said," O Messenger of Allah, then should we not wait for our tqdir provisions, and not do charity? "The Prophet said," Who which is a happy group, he will surely lead to the charity of happy people. And who is included in the wretched group, he will also lead to the charity of the wretched people. Be godly! Every one of you is made easy. The people are happy, they will be facilitated to do charity the happy people. As for the wretched people, they will also be facilitated to do charity for the wretched people. ${ }^{77}$

Then he read the letter Al-Lail verses 5-10: "As for those who give (their wealth in the way of Allah) and devote, and justify the best return, then We will prepare for him an easy way. And as for those who are ignorant and feel themselves sufficient (rich / not faqir / do not need Allah or anyone), and deny the best reward, then We will prepare it for him (the road) which is difficult. "

So it is proper for the mukta muktaqad to be much afraid of Allah the Almighty. Who Has Gotten Many Virtues. ${ }^{78}$

\footnotetext{
${ }^{76}$ Yahya, Habib Usman bin. (t.th). The nature of twenty, p. 12

${ }^{77}$ Yahya, Habib Usman bin. (t.th). The nature of twenty, p. 12

${ }^{78}$ Yahya, Habib Usman bin. (t.th). The nature of twenty, p. 12
} 
Muridan (the Willing / Determining).

It is impossible for God not to determine or to be regulated.

The argument is the proposition of the nature of Iradah. Sourced from Abdullah bin Mas'ud, he said: Um Habibah once prayed, "O Allah, extend the age of my husband Rasulullah, also my father Abu Sufyan, and my brother Mu'awiyah." The Prophet then said to his wife, "That means you plead with God for the doom that has been made, the histories that have been determined, and rizki-rizki that have been divided. The least of it will not be forwarded or suspended from the time. If you plead with Allah that $\mathrm{He}$ is willing to protect you from the torment of hell and the torment of the grave, surely that is better for you. "(Narrated by Muslim). ${ }^{79}$

Then it is appropriate for the muktaqad believer to pray to Allah for the virtues of the world and the hereafter, and to beg to be avoided from evil in the world and in the hereafter. ${ }^{80}$

'Alimun (Who Knows) Impossible Allah the One who is ignorant (stupid)

The argument is the proposition of nature 'Science.

Then it is appropriate for the mukmin muktaqad to always ask for help from Allah in every matter and ask that it be nourished from every evil of the world and the hereafter. ${ }^{81}$

Hayyun (The Living One) Impossible of the God of the Dead.

The argument is Hayah's proposition. So it is appropriate for the mukmin muktaqad to have a lot of trust (surrender in all things) to Allah. ${ }^{82}$

Sami'un (The Hearing). It is impossible for God to be deaf, not to listen.

${ }^{79}$ Yahya, Habib Usman bin. (t.th). The nature of twenty, p. 12

${ }^{80}$ Yahya, Habib Usman bin. (t.th). The nature of twenty, p. 12

${ }^{81}$ Yahya, Habib Usman bin. (t.th). The nature of twenty, p. 13

${ }^{82}$ Yahya, Habib Usman bin. (t.th). The nature of twenty, p. 13 
The argument is the proposition of Sama '. "Surely I (did) as my servant suspected. I was with him when he remembered me. If he remembers Me in his heart, then I will Remember It in My Heart. If he remembers me in a group of people, then I will remember him in a better jama'ah (Allah tells / boasts of people who dhikr and pray in the presence of angels). If he approaches me on an inch, then I will approach him a cubit. If he approaches me a cubit, then I will approach him as soon as possible. If he approaches me while walking. So I approached him hurriedly. Indeed, my reckoning is very fast. "(Hadith Qudsi). ${ }^{83}$

So it is appropriate for mukmin muktaqad to always praise Allah and pray to Him a lot. (And prejudiced well)

Bashiran (who sees). It is impossible for a blind God (Who does not see).

The argument is the proposition of Bashar's nature. Then it is fitting for the mukmin muktaqad to always be ashamed of Allah Who sees him when he sins or leaves the fardhu. ${ }^{84}$

Mutakalliman (Who Said / Said). Impossible Allah the One Who does not say / mute.

The argument is the proposition of the nature of Kalam. As already said, that the Qur'an is Kalamullah. Kalamullah is Qadim. When we read the Qur'an, we are saying what Allah says. So whoever hears the Qur'an should say, "Allah"; so that he remembers that the Qur'an is the Kalam of Allah, Rabbul amin alamin. The Prophet said, "Whoever wants to have a dialogue with God, then read the Qur'an."

So it is appropriate for the mukmin muktaqad to always read the Qur'an with great respect, 'respect and full of ta'zhim with tajwid (tartil) and not by reading qira`ah (Yahya, t.th: 13).

${ }^{83}$ Yahya, Habib Usman bin. (t.th). The nature of twenty, p. 13

${ }^{84}$ Yahya, Habib Usman bin. (t.th). The nature of twenty, p. 13 


\section{Division of the Nature of God and His Understanding}

The nature of Nafsiyah is that which is obligatory for the Essence as long as the Essence is manifest (there is) not caused by a cause. Which includes the nature of nafsiyah is the nature of being.

The nature of Salbiyah / Rejection is a trait that seems to deny the character / something that is not worthy of God. This attribute sanctifies God from the unworthy nature of the perfect God. Which includes the nature of salbiyah is the nature:

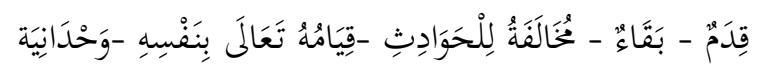

The nature of Maany is every trait that is in the Essence that obliges the Essence of Ma'nawiyah. Which includes the nature of ma'any namely: ${ }^{85}$

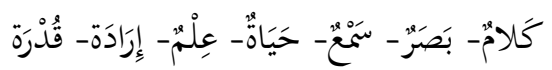

The nature of Ma'nawiyah, which is a matter that remains for the Essence because of the Essence of Ma'ani So these two properties need each other. Which includes the nature of ma'nawiyah namely: ${ }^{86}$

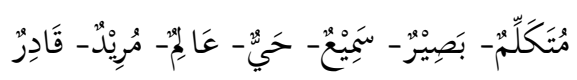

Then the one who must be in God is one, namely to do everything possible or leave it. It is also mandatory for every mukallaf to recite with 9 I'tiqad again. namely: 1). It is impossible for God to obey Him to make everything possible or leave it; that is the opposite of the one who must (jaiz) to God. 2). Exalted by Allah rather than taking the principle of all His actions or from His law. 3). It is impossible for God to take the principle of all His actions or from His law. 4). It is obligatory for everything possible that it has no former / influence with its strength. 5). It is impossible for everything possible that he is a former / influence with his strength. 6). Mandatory I'tiqad that the universe is a huduts (baharu) ". 7). It is impossible for the universe to

${ }^{85}$ Yahya, Habib Usman bin. (t.th). The nature of twenty, p. 13

${ }^{86}$ Yahya, Habib Usman bin. (t.th). The nature of twenty, p. 13 
be qadim (formerly). 8). It is obligatory for everything that may not give a trace to its character. 9). It is impossible for all possible to give traces to his character. ${ }^{87}$

Thus 'aqaid 50 which is the ma'a Laa Ilaaha Illallaah. Because the laa Ilaaha is that there is no worship with haqq (actually). And what is truly worshiped is the Rich (Which Doesn't Need) from the other than Him, and faqir (requires) to Him other than Him. Obviously the Wealth of Allah from those other than Him, and faqir to Him other than Him (the proof is 50 aid aqaid that has been). The one who declares the Rich God from every one besides Him ", namely: 14 aqaid below with his opponent. Namely: form, qidam, baqa ', mukhalafatu lil hawadist, qiyamu bi nafsishi, sama', basar, kalam, sami'un, basirun, mutakallimun, Impossible (to Allah) the obligation to Him to make everything possible or leave it, Most Holy of Allah Taking rules and (obligatory) everything that might not give a mark with its strength. Which states "Willing to Him every one besides Him", namely: 11 aqaid below with his opponent. Namely: Wahdaniyat, qudrat, iradat, knowledge, life, qadirun, muridun, alimun, hayyun, (obligatory) the universe is new and (obligatory) which besides gives no trace of its nature. ${ }^{88}$

Then below is the shifat-shifat which is obligatory and impossible for the Apostles. Namely: Siddiq (true), impossible kadzib (lie), Amanah (trustworthy), impossible betrayal, Tabligh (conveying), impossible katiman (hiding) and Fathanah (perfect understanding) The one who must (jaiz) for the Apostles is one, that is, his body fights like an ordinary human. For example eating, drinking, sleeping and waking up, getting sick. It is impossible for them to become deprived (unlike normal humans) like crazy. ${ }^{89}$

\section{CONCLUSION}

Aqeedah is a faith that is certainly firm with the Rububiyyah of Allah, His Uluhiyyah, His Apostles, Doomsday, good and bad destiny, all that is contained in the unseen problem, the points of religion and what has been agreed upon by Salafush Salih with submission round to God both in his commands, his law and

${ }^{87}$ Yahya, Habib Usman bin. (t.th). The nature of twenty, p. 14

${ }^{88}$ Yahya, Habib Usman bin. (t.th). The nature of twenty, p. 14

${ }^{89}$ Yahya, Habib Usman bin. (t.th). The nature of twenty, p. 15 
obedience to him and imitating the Prophet. The Science of Tawheed is the Science which discusses the form of Allah, the attributes which are obligatory for Him, the attributes which are attributed to Him, and the characteristics which must be completely removed from Him (impossible). Also discusses the Apostles of God to determine the truth of the treatise, what is obligatory on him, things that are connected (attributed) to themselves and things that are forbidden to connect to themselves.

Five Pillars of Islam, the first pillar of the science of monotheism or aqeedah. Learning tauhid must understand the three laws, namely law 'Aqal, adat and syariat. These three laws are called theories of philosophical aqeedah, the easiest theory to know God with the twofold concept. It consists of four parts, namely the nature of nafsiyah (wujud), salbiyah (qidam, baqa, mukhalafatu lil hawadist, qiyamu bi nafsihi and wahdaniyat), maknawi (qudrat, iradat, knowledge, hayat, sama ', basar and qalam) and maknawiyah (presence, student, aliman, hayyan, sami'an, basiran and mutakalliman). These twenty traits have ta'aluq, namely the nature of qudrat and iradat ta'aluq ta'sir, the same nature ', basar and the knowledge of ta'aluq incisive, the nature of kalam ta'aluq is done. The twenty characteristics are grouped into two properties, namely istighna 'and iftiqar. This is the core content of the content "laa ilaaha illa allah". The second monotheism is the monotheism of the Prophet Muhammad who has the mandatory four characteristics, namely: siddiq, trust, tabigh and fatanah.

\section{BIBLIOGRAPHY}

Abadi. F. (1996). Qomus Al-Mubith. Ath Thaba'ah Al Khamisah. Bairut: Mu'assah AlRisalah.

Ahmad, Muhammad Abdul Qadir. (2012). Islamic Teaching Methodology, happened. HA. Mostopha. Jakarta: Rineka Cipta.

Al-Atsari, Abdullah bin Abdul Hamid. (2010). Al-Wajiz fii Aqiidatis Salafis Shaalih (Sunnah wal Jama'ah Ablis), or Essence of Aqidah Ablus Sunah wal Jama'ab), happened. Farid bin Mubammad Bathathy. Library of Imam Shafi'i.

Al-Banna, Hasan. (2003). Islamic Aqeedah, happened. H. Hassan Baidlowi. Bandung: alMa'arif.

Al-Burnikan, Ibrahim Muhammad bin Abdullah. (2010). Introduction to the Study of Islamic Aqeedah. Muhammad Anis Matta. Jakarta: Robbani Press. 
Al-bustani, Fuad Iqrami. (2000). Munjid Ath-Thullab. Beirut: Dar Al-Masyriqi.

Anis, Ibrahim et al. (1972). Al-Mu'jam Al-Wasit. Egypt: Majma 'Al-Lughah AlArabiyah.

Asmuni, M. Yusran. (1989). Indonesia Dictionary. Department of P \& K, Jakarta: PT. Raja Grafindo Persada

Asmuni, M. Yusran. (2003). Science of Tawheed. Jakarta: PT. Raja Grafindo Persada.

Husein, Machnun. (2011). Get to know Islam at a glance. Jakarta: Bumi Aksara.

Ilyas, Yunahar. (2013). Lecture on Islamic Aqeedah. Yogyakarta: Institute of Islamic Studies and Practicing (LPPI) of Muhammadiyah University of Yogyakarta.

Jawas, Yazid bin Abdul Qadir. (2006). Syah Aqeedah Ablus Sunnah wal Jama'ah. Library of Imam Ash-Shafi'i.

Mandzur, Ibnu. (2002). Oral al-Arab. Cairo: Darul hadith.

Mas'ud, Jubaran. (1976). Raid Ath-Thullab. Beirut: Dar Al'ilmi Lilmalayyini.

Munawwir. Ahmad Warson. (1997). Dictionary of Al-Munawwir. (Surabaya: Progressive literature.

Prodjodikoro, Suyatno. (2011). Aqidah Islamiyyah and its Development. Yogyakarta: Contributions Offset.

Rais, Amin. (2010). Taubid of Social Formula Combat Gaps. Mizan Bandung.

Rashid, David. (2010). Islam in various dimensions. Jakarta: GIP. h

RI Ministry of Religion. (2015), Al-Qur'an and Translation. Semarang: Toha Putra.

Sabran, Dja'far. (2016). Minutes of Tawheed. Cipitat: Mitra Fajar Indonesia.

Syafii. (2012). "From the Science of Tawhid / Kalam Science to Theology: Epistemological Analysis". Theology, Volume 23, Number 1, 1-15

Yahya, Habib Usman bin. (t.th). The nature of twenty. Jeddah: Singgapore.

Zaini, Shahminan. (2010). Lecture on the Creed of Islam. Surabaya: Al Ikhlas. 